\title{
(2) The Impact of Human Capital Development on aße Economic Growth in Ethiopia: Evidence from ARDL Approach to Co-Integration
}

\section{Kidanemariam Gidey Gebrehiwot}

Institute of Public Management and Development Studies (IPMDS), School of Graduate Studies, Ethiopian Civil Service University, ETHIOPIA

E-mail for correspondence: kidugidey@gmail.com

Cell Phone: +251-0914004527

Received: Oct 30, 2014;

Accepted: Nov 17, 2014;

Published: Dec 25, 2014

Source of Support: Nil

No Conflict of Interest: Declared

\begin{abstract}
The main objective of the study was to investigate the long run and short run impact of human capital on economic growth in Ethiopia (using real GDP per capita, as a proxy for economic growth) over the period 1974/75-2010/2011. The ARDL Approach to Co-integration and Error Correction Model are applied in order to investigate the long-run and short run impact of Human capital on Economic growth. The finding of the Bounds test shows that there is a stable long run relationship between real GDP per capita, education human capital, health human capital, labor force, gross capital formation, government expenditure and official development assistance. The estimated long run model revels that human capital in the form of health (proxied by the ratio of public expenditure on health to real GDP) is the main contributor to real GDP per capita rise followed by education human capital (proxied by secondary school enrolment). Such findings are consistent with the endogenous growth theories which argue that an improvement in human capital (skilled and healthy workers) improves productivity. In the short run, the coefficient of error correction term is -0.7366 suggesting about 73.66 percent annual adjustment towards long run equilibrium. This is another proof for the existence of a stable long run relationship among the variables. The estimated coefficients of the short-run model indicate that education is the main contributor to real GDP per capita change followed by gross capital formation (one period lagged value) and government expenditure (one period lagged value). But, unlike its long run significant impact, health has no significant short run impact on the economy. Even its one period lag has a significant negative impact on the economy.

The above results have an important policy implication. The findings of this paper imply that economic performance can be improved significantly when the ratio of public expenditure on health services to GDP increases and when secondary school enrolment improves. Such improvements have a large impact on human productivity which leads to improved national output per capita. Hence policy makers and / or the government should strive to create institutional capacity that increase school enrolment and improved basic health service by strengthening the infrastructure of educational and health institutions that produce quality manpower. In addition to its effort, the government should continue its leadership role in creating enabling environment that encourage better investment in human capital (education and health) by the private sector.
\end{abstract}

Keywords: Ethiopia, Economic Growth, Human capital, Education, Health, ARDL method of Cointegration, ECM model

\section{INTRODUCTION}

Human capital refers to the "knowledge, skills, competence and attributes embodied in individuals that facilitate the creation of personal, social and economic well-being" (OECD, 2001:17). Recent growth literature has given more emphasis to the consequence of human capital in economic growth and development .Generally; economic growth and development theorists argued that human capital has a substantial effect on economic growth and development (Kefela and Ren, 2007). For instance, According to Harbison (1971) wealth of a nation is critically determined by its level of human capital. For him, differences in the level of socio-economic development across nations is determined not so much by natural resources and the stock of physical capital but 
by the quality and quantity of human resources. Similarly, Lucas (1988); Romer (1990); Mankiw, Romer, and Weil (1992 and Bergheim (2005) argued that human capital is crucial so as to increase the productivity of labor and physical capital. In addition, ILO report (2003) as cited by Patron (2006: 3) states that, "the knowledge and skills endowment of a country's labor force, rather than its physical capital, determines its economic and social progress, and its ability to compete in the world economy". In other words, human capital is the main source of knowledge and a guide for the implementation of this knowledge in the production process.

Even though there is an argument on the importance of human capital for economic growth of any country, it is still controversial that what factors should be considered as human capital and how to measure it. In most of the studies education or health related indicators are employed as a proxy for human capital (Qadri and Waheed, 2011).

Like other countries, Ethiopia has devoted much resource and efforts to the education and health sectors anticipating productivity improvement of the citizens and thereby economic growth. These resources are cost to the society not only because they are economic resources but also because they have alternative uses. Therefore, investigating the relationship between human capital (resources devoted to this sector) and economic growth may be a big concern to policy makers and even to the society.

Some researchers have tried to investigate the relationship between human capital development and economic growth in Ethiopia. For instance, using school enrollment as a proxy for human capital, Seid (2000) found an insignificant impact of human capital on output level. Similarly Wubet (2006) has got the same result that proves the non existence of any relationship between the two macroeconomic variables. But, their approach of measuring human capital ignores the health aspect of human capital development, while both education and health are important component of human capital.

On the other hand, using public spending on education and health sector as a proxy for investment in human capital development, Teshome (2006) found a positive impact of human capital development on economic growth in Ethiopia. This finding is reinforced by Tofik (2012) who found a positive and significant relationship between capital spending on human capital and economic growth. But both of them didn't show the separate impact of the health and education sector on economic growth. In addition Tofik failed to incorporate the recurrent human capital expenditure account of the government. Since both education and health are important elements of human capital, using both indicators is relatively better measure of human capital than using education or health indicators alone. Therefore, the author of this paper has used both the education and health indicators so as to empirically analyze the effects of human capital development on economic growth by taking secondary school enrolment rate as a proxy for human capital in the education area and the ratio of public expenditure on health to GDP as a proxy for human capital in the health area.

\section{ReseARCh OBJectives}

The main objective of the study is to analyze the impact of human capital development on economic growth in Ethiopia over the period 1974/75-2010/11. The study will try to address the following specific objectives:

- To empirically evaluate the impact of human capital development on economic growth in Ethiopia, both in the short-run and in the long-run.

- To analyzes the causal relationship between human capital development and economic growth in Ethiopia.

- To derive policy implications from the empirical analysis.

\section{RESEARCH QUESTIONS}

- Does human capital development have a significant long-run and short-run impact on economic growth in Ethiopia?

- Is there a causal relationship between human capital development and economic growth in Ethiopia?

\section{SigNIFICANCE OF THE STUdY}

This study is expected to generate the following benefits:

- It will improve the practical knowledge and skill of the researcher of this study by making familiar with factual evidence on the macroeconomic problems.

- It will produce general information on the relationship between human capital development and economic growth.

- It will serve as a spring board for further studies on human capital development and economic growth.

- It will generate evidences for policy implications that aim to analyze the interaction of human capital development and economic growth.

\section{SCOPE AND LIMITATION OF THE STUdY}

The study has used 37 years annual data covering from the period 1974/75 to 2010/11. The study excludes comparative analysis with other countries. In order to empirically analyze the long run and short run relationship between human capital development and economic growth (real GDP per capita), only secondary school enrolment is used as a proxy for the education human capital. On the other hand, the ratio of total government expenditure on health to GDP is used as a proxy for health human capital indicator. In this research, though learning on the job (experience) could have an impact on human capital development, only formal education is used as a proxy for human capital formation in the education area. On the other hand, the research didn't include the impact of private expenditures on 
health. But, since most of the basic health service is provided by the government, government expenditure on health can explain the health human capital created in Ethiopia. Further, though only two variables (labor force and official development assistance) are taken from international organizations (UNCTAD and WB), such mixed sources of data may have little impact on the quality of the results.

\section{THEORETICAL FRAMEWORK AND MODEL SPECIFICATION}

Different scholars have designed different conceptual frameworks that incorporate human capital as one of the determinant factor of economic growth. Among those scholars, Mankiw, Romer and Weil (1992) and Weil (2009) has accommodated human capital as an independent factor of production in their empirical analysis. Griffin and Knight (1990) as cited by Appleton and Teal (1998) has also used health and education as determinants of GDP per capita assuming education, good health and longevity are essentially valuable output determinants. These researchers have employed the human capital augmented Solow growth model (Cobb- Douglas production function) as their framework, specifying output/output per worker as dependent variable while labor, physical capital and human capital are dependent variables. Bernanke and Gurkanak (2001) also applied Cobb- Douglas production function so as to analyze the relationship between human capital and economic growth. Duma (2007) who studied the sources of growth in Sri Lanka has used a human capital augmented CobbDouglas production function in the study, taking output growth as a dependent variable while growth in labor, growth in physical capital and growth in human capital were taken as explanatory variable. Madsen, Saxena, and Ang (2008) who studied the relationship between human capital and economic growth of India have also used the human capital augmented production function and employed the co-integration method was adopted for their estimation.

The general form of the human capital augmented CobbDouglas production is shown below:

$$
\mathrm{Y}_{\mathrm{t}=} \mathrm{K}_{\mathrm{t}}^{\alpha} \mathrm{H}_{\mathrm{t}}^{\beta}(\mathrm{AL})_{\mathrm{t}}^{1-\alpha-\beta} \mathrm{u}
$$

By transforming the equation in to log-linear form:

$$
\ln \mathrm{Y}_{\mathrm{t}}=\alpha \ln \mathrm{K}_{\mathrm{t}}+\beta \ln \mathrm{H}_{\mathrm{t}}+(1-\alpha-\beta) \ln \left(\mathrm{AL}_{\mathrm{t}}\right)+
$$

Where,

$\mathrm{Y}$ is output level;

Physical capital with respect to output

$\mathrm{K}$ is level of physical capital

Human capital with respect to output

$\mathrm{H}$ is level of Human Capital

$\mathrm{L}$ is the level labor force,

$\mathrm{v}$ is an error term

$\alpha$ is Elasticity of

A is level of Productivity/technology
The above model can be transformed in to empirically estimable form as follows:

According to Mankiw, Romer and Weil (1992) , Labor and technology are assumed to grow at the rates $\mathrm{n}$ and $\mathrm{g}$ and the number effective units of labor $\left(\mathrm{AL}_{t}\right)$ grows at the rate $\mathrm{n}+\mathrm{g}$.

$$
\begin{aligned}
& \mathrm{L}_{\mathrm{t}}=\mathrm{L}_{0} \mathrm{e}^{\mathrm{nt}} \\
& \mathrm{A}_{\mathrm{t}}=\mathrm{A}_{0} \mathrm{e}^{\mathrm{gt}}
\end{aligned}
$$

Assuming constant shares of output denoted by $s_{k}$ and $s_{h}$ are devoted to gross investment in physical capital and human capital respectively we can write:

$$
\begin{aligned}
& I K_{t}=s_{k} Y_{t} \\
& I H_{t}=s_{h} Y_{t}
\end{aligned}
$$

Where $\mathrm{IK}_{\mathrm{t}}$ and $\mathrm{IH}_{\mathrm{t}}$ are investments in physical capital and human capital respectively.

Letting $\mathrm{k}=\frac{\mathrm{K}}{\mathrm{AL}}$ as the stock of physical capital per effective unit of labor, $h=\frac{H}{A L}$ as the stock of human capital per effective unit of labor, $y=\frac{Y}{A L}$ as the level of output per effective unit of labor, $\mathrm{n}$ is the growth rate of labor, $\mathrm{g}$ is the rate of technological change and $\mathrm{d}$ is the common (time-invariant) depreciation rate, we can derive the time path (differentiation with respect to time) of $\mathrm{k}$ and $\mathrm{h}$ as follows (Mankiw, Romer and Weil, 1992).

$$
\begin{aligned}
& \frac{\partial \mathrm{k}}{\partial \mathrm{t}}=\dot{\mathrm{k}}=\mathrm{s}_{\mathrm{k}} \mathrm{y}_{\mathrm{t}}-(\mathrm{n}+\mathrm{g}+\mathrm{d}) \mathrm{k}_{\mathrm{t}} \\
& \frac{\partial \mathrm{h}}{\partial \mathrm{t}}=\dot{\mathrm{h}}=\mathrm{s}_{\mathrm{h}} \mathrm{y}_{\mathrm{t}}-(\mathrm{n}+\mathrm{g}+\mathrm{d}) \mathrm{h}_{\mathrm{t}}
\end{aligned}
$$

Under the assumption that $\alpha+\beta<1$ (i.e. decreasing returns to scale), this system of equations can be solved to obtain steady-state values of $\mathrm{k}^{*}$ and $\mathrm{h}^{*}$ defined by:

$\mathrm{k}_{\mathrm{t}}^{*}=\left[\frac{\mathrm{s}_{\mathrm{k}}{ }^{1-\beta} \mathrm{s}_{\mathrm{h}}{ }^{\beta}}{\mathrm{n}+\mathrm{g}+\mathrm{d}}\right]^{(1 / 1-\alpha-\beta)}$

In natural logarithm form:

$$
\begin{aligned}
& \ln k_{t}^{*}=\frac{1-\beta}{1-\alpha-\beta} \ln s_{k}+\frac{\beta}{1-\alpha-\beta} \ln s_{h^{-}} \frac{1}{1-\alpha-\beta} \ln (n+g+d) \\
& h_{t}^{*}=\left[\frac{s_{k}{ }^{1-\alpha} s_{h}{ }^{\alpha}}{n+g+d}\right]^{(1 / 1-\alpha-\beta)}
\end{aligned}
$$

In natural logarithm form:

$\ln \mathrm{h}_{\mathrm{t}}^{*}=\frac{1-\alpha}{1-\alpha-\beta} \ln \mathrm{s}_{\mathrm{k}}+\frac{\alpha}{1-\alpha-\beta} \ln \mathrm{s}_{\mathrm{h}}-\frac{1}{1-\alpha-\beta} \ln (\mathrm{n}+\mathrm{g}+\mathrm{d})$ 
Substituting these two equations into the original production function (equation 1) and taking logs yields the expression for the steady-state output $\left(\mathrm{y}_{\mathrm{t}}^{*}\right)$ :

$\ln y_{t}^{*}=\ln \frac{y_{t}}{L_{t}}=\ln A_{t}+g_{t}-\frac{\alpha+\beta}{1-\alpha-\beta} \ln (n+g+d)+\frac{\alpha}{1-\alpha-\beta}$ $\ln s_{\mathrm{k}}+\frac{\beta}{1-\alpha-\beta} \ln \mathrm{s}_{\mathrm{h}}$

Since $\ln A_{t}$ is not observable, it will be captured by the error term (Mankiw, Romer and Weil, 1992). Similarly, $g_{t}$ is not observable and its parameter cannot be distinguished from the constant term empirically (Bassanini and Scarpetta, 2001). Hence, the estimated basic empirical growth equation could be expressed as follows:

$\ln y_{t}^{*}=\ln \frac{y_{t}}{L_{t}}=C \quad+\frac{\alpha+\beta}{1-\alpha-\beta} \ln (n+g+d)+\frac{\alpha}{1-\alpha-\beta} \ln s_{k}+$ $\frac{\beta}{1-\alpha-\beta} \ln s_{h} \ldots . .(3)$

Therefore, based on this theoretical framework developed by Mankiw, Romer and Weil (1992), the following empirically estimable log-linear type of model (with some modification to accommodate other additional variables) is specified.

$\operatorname{LnGDPPC}_{t}=$

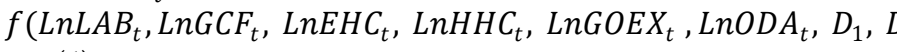
.....(4)

Where:

LnGDPPC $_{t}=$ Natural logarithm of real GDP per capita at time $t$.

$\mathrm{LnLAB}_{t}=$ Natural logarithm of labor force growth rate at time $t$.

$\mathrm{LnGCF}_{t}=$ Natural logarithm of gross capital formation at time $t$.

LnEHC $_{t}=$ Natural logarithm of education human capital at time $t$.

$\mathrm{LnHHC}_{t}=$ Natural logarithm of health human capital at time $t$.

LnGOEX $_{t}=$ Natural logarithm of total government expenditure at time $t$

LnODA $_{t}=$ Natural logarithm of official development assistance at time $t$.

$D_{1}$ and $D_{2}$ are dummy variables for policy change and recurrent drought

Generally, the empirical analyses related to human capital and economic growth mostly rely on measures of formal education as a proxy for human capital formation by ignoring the contribution of health on human capital development, while both education and health are important for human capital development (Gundlach, 1996; Karagiannis \& Benos (2009)).

To avoid such limitations, many researchers have used both of the education and health measures as a proxy for human capital. For instance, Karagiannis \& Benos (2009) have used enrolment rates, student/teacher ratios for the educational indicators and number of medical doctors and hospital beds for the health indicators. On the other hand, Qadri and Waheed (2011) have used education indicator (enrolment rates) and health indicator (share of total government expenditure on health to GDP). Barro (2003) has also measured human capital using education (educational attainment) and health (life expectancy). Including both the education and health indicators are relatively better measure of human capital than using education or health indicators alone. Because it expresses the notion that both education and health are an important elements of human capital.

With regard to this paper, both the education and health indicators separately are used so as to empirically analyze the effects of human capital development on economic growth. The secondary school enrolment rate level is used as a proxy for human capital in the education area. On the other hand, the share of total government expenditure on health to GDP is used as a proxy for health human capital in the health area. The availability of data in Ethiopia and other international databases related to education and health indicators of Ethiopia are also more suitable to use such techniques of measurement than the other alternative measures discussed above.

\section{Data Sources and Measurement of Variables}

The study has used 37 year annual data from 1974/752010/11. Most of the data is collected from Ministry of Finance and Economic Development (MOFED), Ethiopian Economic Association (EEA) and National Bank of Ethiopia (NBE). Some of the data is also collected from international organizations (such as, UNCTAD and World Bank CD-ROM). The detailed sources of data for each variable are described in table 2.

Table 1: Summary of data source by variable

\begin{tabular}{|c|c|c|}
\hline Type of variable & Unit/Proxy & Source \\
\hline $\begin{array}{l}\text { Real GDP per } \\
\text { capita }\end{array}$ & $\begin{array}{l}\text { Real Gross Domestic product } \\
\text { per capita }\end{array}$ & NBE \\
\hline $\begin{array}{l}\text { Physical Capital } \\
\text { stock }\end{array}$ & $\begin{array}{l}\text { Ratio of real Gross Capital } \\
\text { Formation to real GDP. }\end{array}$ & MoFED \\
\hline Labor force & Labor force growth rate & UNCTAD \\
\hline $\begin{array}{l}\text { Education } \\
\text { Human capital }\end{array}$ & Secondary school enrollment & $\begin{array}{l}\text { MoE and } \\
\text { EEA }\end{array}$ \\
\hline $\begin{array}{l}\text { Health Human } \\
\text { capital }\end{array}$ & $\begin{array}{l}\text { Ratio of government } \\
\text { expenditure on health } \\
\text { (recurrent and capital) to GDP. }\end{array}$ & $\begin{array}{l}\text { MOFED } \\
\text { and EEA }\end{array}$ \\
\hline $\begin{array}{l}\text { Total } \\
\text { government } \\
\text { expenditure }\end{array}$ & $\begin{array}{l}\text { Ratio of total government } \\
\text { expenditure (recurrent and } \\
\text { capital) to GDP }\end{array}$ & $\begin{array}{l}\text { NBE and } \\
\text { MoFED }\end{array}$ \\
\hline $\begin{array}{l}\text { Official } \\
\text { development } \\
\text { assistance }\end{array}$ & $\begin{array}{l}\text { Ratio of Official development } \\
\text { assistance to GDP. }\end{array}$ & $\begin{array}{l}\text { World } \\
\text { Bank }\end{array}$ \\
\hline
\end{tabular}

Note: All of the variables are included in the model in real terms 
The descriptions and measurements of the dependent and the explanatory variables that are included in the model of this paper are explained as follows:

\section{Real GDP Per Capita (GDPPCt)}

Like the studies made by Mankiw, Romer and Weil (1992), Barro and Lee (1993), Benhabib and Spiegel (1994) and Barro and Sala-i-Martin (1995; 2004), Real GDP per capita that indicate the total amount of the market value of all domestically produced final goods and services divided by total population is taken as a proxy for economic growth (dependent variable).

\section{Share of Real Gross Capital Formation to GDP (GCFt)}

It is a proxy for physical capital stock in the economy and it is derived by dividing the gross fixed capital formation adjusted through GDP deflator to real GDP. Barro and Sala-I-Martin $(1995 ; 2004)$ shows that the sign expected from the coefficient GCF is positive, because the accumulation of the capital is supposed to favor the growth of the real GDP by fostering further production of new goods and services.

\section{Labor}

Theoretically, labor force is a major element for sustainable rate of economic expansion. It could be the engine of growth for labor intensive economies like Ethiopia. But if it couldn't be used efficiently and if it is less productive, it may be a burden for the economy because of high rate of unemployment. It is incorporated in the model in its growth rate.

\section{Human Capital Development}

Human capital is a factor influencing labour productivity because it facilitates the absorption of new technology, increases the rate of innovativeness and promotes efficient management (Adamu, 2003; as cited in Sankay, Ismail, and Shaari, 2010). Consequently, for high labor productivity, investment in human capital is termed as endogenous factor that enhance accumulation of physical capital through knowledge, skills, attitudes and health status of the people who participate in the economic process. Therefore, this variable is included in the model to represent the "knowledge, skills, competence and attributes embodied in individuals that facilitate the creation of personal, social and economic well-being. It is represented by the share of public health expenditure (recurrent and capital) to GDP and secondary school enrolment. Therefore, higher level of human capital development in the form of education and health are expected to have a positive impact on economic growth.

\section{Ratio of Government Expenditure to Real GDP}

This variable refers to the ratio of the sum of recurrent and capital budget of the Ethiopian government to real GDP. To avoid double counting government expenditure on human capital is deducted from total government expenditure .Similarly, since ODA is included in the model as one explanatory variable; government expenditure is taken only the expenditures from domestic sources (excluding the external assistance and loan). It is entered in to the model as a share of GDP. Since, budgetary expansion would boost the economy and would cause an increase in the real GDP growth rate, the sign expected from the coefficient of public spending is positive

\section{Ratio of Official Development Assistance to Real GDP}

The view on the relationship between official development assistance aid and economic growth can be classified in to three. The first view is that aid has a positive contribution to the socio-economic status of the recipient country. The second argument rests on the idea that aid might lead to poor or negative productivity by discouraging alternative development policies and institutions (Rajan and Subramanian, 2005; Ekanayake and Chatrna ,2008). The other argument is that the marginal contribution of aid depends on the institutional environment (policy) of the recipient country. If there is good economic policy environment, it is crucial for the efficient allocation of aid to investment which has a positive impact on the economy. However, it will have little or no impact on economic growth if there is institutional destruction and capacity constraints (Hansen and Tarp, 2000).Therefore, since Ethiopia is among the main aid recipient countries in Africa; it is entered in to the model as one control variable.

\section{Dummy Variable}

Changes in economic policies can influence the performance of the economy through investment on human capital and infrastructure, improvement in political and legal institutions and so on (Easterly, 1993). On the other hand, recurrent drought and bad weather condition have a negative impact on the economy, especially in developing countries that are predominantly dependent on agriculture. Therefore, policy change dummy (D1) and recurrent drought dummy (D2) are added in to the model. The dummy for changes in economic policies take zero for the period 1974/751991/92 and one otherwise. Similarly, the drought dummy takes zero, if there was relatively good weather condition and one if there was drought. The drought periods are determined based on the findings of (Webb, Braun, and Yisehac, 1992; Viste, Korecha, and Sorteberg, 2012 ).

All of the variables discussed above are given in logarithm form (except the policy change and drought dummy). The log-linear form of specification enables the researcher to interpret the coefficient of the dependent variables directly as elasticity with respect to the independent variables (Sarmad, 1988). In addition it is also useful for accommodating the hetreoskedasticity problem (Goldstein and Khan, 1976). 


\section{Results AND Discussion}

\section{Augmented Dicky-Fuller Unit Root Test}

In order to determine the degree of stationarity, a unit root testing is carried out through the standard Augmented Dicky-Fuller (ADF) test. This test was undertaken to check the order of integration of the variables. The test was done for two alternative specifications. First it is tested with constant but no trend, and then it is tested with constant and trend (See Table.3).

Table 2: ADF unit root test results

\begin{tabular}{|c|c|c|}
\hline $\begin{array}{c}\text { Variables } \\
\text { (At level and } \\
\mathbf{1}^{\text {st }} \text { difference) }\end{array}$ & $\begin{array}{c}\text { t-stat } \\
\text { (with intercept } \\
\text { but no rend) }\end{array}$ & $\begin{array}{c}\text { t-stat } \\
\text { (with intercept } \\
\text { and trend ) }\end{array}$ \\
\hline LnLAB & -2.3066 & -1.9913 \\
$\Delta$ LnLAB & $-5.7451^{* * *}$ & $-5.8121^{* * *}$ \\
LnGCF & -1.5491 & $-3.4126^{*}$ \\
$\Delta$ LnGCF & $-4.3045^{* * *}$ & $-4.2318^{* *}$ \\
LnEHC & -0.2712 & -1.9382 \\
$\Delta$ LnEHC & $-4.0889^{* * *}$ & $-3.9826^{* *}$ \\
LnHHC & -1.1560 & $-4.2745^{* * *}$ \\
$\Delta$ LnHHC & $-5.5383^{* * *}$ & $-5.4463^{* * *}$ \\
LnGOEX & -2.6037 & -2.4077 \\
$\Delta$ LnGOEX & $-4.6049^{* * *}$ & $-4.6030^{* * *}$ \\
LnODA & -1.3859 & -2.0645 \\
$\Delta$ LnODA & $-6.3378^{* * *}$ & $-6.3233^{* * *}$ \\
LnGDPPC & 0.3360 & -0.5261 \\
$\Delta$ LnGDPPC & $-4.5721^{* * *}$ & $-5.4292^{* * *}$ \\
\hline
\end{tabular}

Source: Author's Calculations.

Note: The rejection of the null hypothesis is based on MacKinnon (1996) critical values. Akaike information criterion (AIC) is used to determine the lag length while testing the stationarity of all variables. The ${ }^{* * *},{ }^{* *}$ and * sign indicates the rejection of the null hypothesis of nonstationary at $1 \%, 5 \%$ and $10 \%$ significant level respectively

\section{Long run ARDL Bounds Tests For Co-integration}

The first task in the bounds test approach of cointegration is estimating the ARDL model specified in equation (22) using the appropriate lag-length selection criterion. In this paper Akaike Information Criterion (AIC) was taken as a guide and a maximum lag order of 2 was chosen for the conditional ARDL model. Then F-test through the Wald-test (bound test) is performed to check the joint significance of the coefficients specified in equation (22). The Wald test is conducted by imposing restrictions on the estimated long-run coefficients of real GDP per capita, labor force growth, gross capital formation, education human capital, health human capital, government expenditure and official development assistance. The computed F-statistic value is compared with the lower bound and upper bound critical values tabulated in Table CI (III) case IV of Pesaran, Shin, and Smith (2001) and Appendix-X case V of Narayan (2005).

Table 3: Pesaran et al. (2001) and Narayan (2005) lower and upper bound critical value

\begin{tabular}{|l|c|c|c|c|}
\hline \multirow{2}{*}{ Description } & \multicolumn{2}{|c|}{ At 1\% level } & \multicolumn{2}{c|}{ At 5 \% level } \\
\cline { 2 - 5 } & $\begin{array}{l}\text { Lower } \\
\text { bound, } \\
\text { I(0) }\end{array}$ & $\begin{array}{l}\text { Upper } \\
\text { bound } \\
\text { I(1) }\end{array}$ & $\begin{array}{l}\text { Lower } \\
\text { bound } \\
\text { I(0) }\end{array}$ & $\begin{array}{l}\text { Upper } \\
\text { bound } \\
\text { I(1) }\end{array}$ \\
\hline $\begin{array}{l}\text { Pesaran (2001) critical } \\
\text { values for K=6 }\end{array}$ & 3.60 & 4.90 & 2.87 & 4.00 \\
\hline $\begin{array}{l}\text { Narayan (2005) critical } \\
\text { values for K=6 }\end{array}$ & 4.53 & 6.26 & 3.33 & 4.70 \\
\hline
\end{tabular}

Source: Pesaran, Shin, and Smith (2001) and Narayan (2005) tables.

As it is depicted in Table-4 below, with an intercept and trend, the calculated F statistics 9.536 is higher than the Pesaran, Shin, and Smith (2001) and Narayan (2005) upper bound critical values at $1 \%$ level of significance. This implies that the null hypothesis of $\beta_{1}=\beta_{2}=\beta_{3}=$ $\beta_{4}=\beta_{5}=\beta_{6}=\beta_{7}=0$ (there is no long-run relationship) against its alternative $\beta_{1} \neq \beta_{2} \neq \beta_{3} \neq \beta_{4} \neq \beta_{5} \neq \beta_{6} \neq \beta_{6} \neq$ $\beta \neg \neq 0$ (there is long-run relationship) is rejected based on the Pesaran, Shin, and Smith (2001) and Narayan (2005) critical values at $1 \%$ level of significance.

\section{Long-run Model Estimation}

This result indicates us the existence of a long-run relationship among real GDP per capita, labor force, gross capital formation, education human capital, health human capital, government expenditure and official development assistance. After confirming the existence of long-run co-integration relationship among the variables, the estimated long-run relationship between the variables are estimated and the estimated coefficients after normalizing on real GDP per capita (GDPPC) are reported in Table 6.

Table 4: Estimated long run coefficients using the Autoregressive Distributed Lag Approach: ARDL $(1,0,2,2,2,2,1)$ selected based on Akaike Information Criterion

\begin{tabular}{|l|l|l|l|l|}
\hline \multicolumn{5}{|l|}{ Dependent variable is LnGDPPC } \\
\hline Regressor & Coefficients & S.E & T-Ratio & Prob \\
\hline LnLAB & 0.09724 & 0.11326 & 0.8586 & 0.404 \\
LnGCF & -0.74489 & 0.37269 & -1.9987 & 0.064 \\
LnEHC & 0.50965 & 0.14294 & 3.5656 & $0.003^{* * *}$ \\
LnHHC & 0.59292 & 0.21315 & 2.7817 & $0.014^{* *}$ \\
LnGOEX & -0.45653 & 0.18191 & -2.5096 & $0.024^{* *}$ \\
LnODA & -0.17643 & 0.06854 & -2.5740 & $0.021^{* *}$ \\
$\begin{array}{l}\text { Policy change } \\
\text { dummy(D1) }\end{array}$ & 0.00804 & 0.10184 & 0.0790 & 0.938 \\
$\begin{array}{l}\text { Drought } \\
\text { dummy (D2) }\end{array}$ & -0.16527 & 0.04093 & -4.0377 & $0.001^{* * *}$ \\
$\begin{array}{l}\text { Constant } \\
\text { Trend }\end{array}$ & 4.22870 & 1.80160 & 2.3472 & $0.033^{* *}$ \\
\hline
\end{tabular}




\begin{tabular}{|l|l|l|r|}
\hline R-Squared & 0.98729 & $\begin{array}{l}\text { S.D. of Dependent } \\
\text { Variable }\end{array}$ & 0.23960 \\
\hline $\begin{array}{l}\text { R-Bar- } \\
\text { Squared }\end{array}$ & 0.97118 & $\begin{array}{l}\text { Residual Sum of } \\
\text { Squares }\end{array}$ & 0.02482 \\
\hline $\begin{array}{l}\text { S.E. of } \\
\text { Regression }\end{array}$ & .04068 & $\begin{array}{l}\text { Equation Log- } \\
\text { likelihood }\end{array}$ & 77.2398 \\
\hline F-stat. & $\begin{array}{l}61.305 \\
{[0.000]}\end{array}$ & $\begin{array}{l}\text { Akaike Info. } \\
\text { Criterion }\end{array}$ & 57.2398 \\
\hline DW-statistics & 2.1965 & $\begin{array}{l}\text { Schwarz Bayesian } \\
\text { Criterion }\end{array}$ & 41.6863 \\
\hline $\begin{array}{l}\text { Mean of Dep. } \\
\text { Variable }\end{array}$ & 7.0529 & & \\
\hline
\end{tabular}

Source: Author's Calculations

Note: The ${ }^{* * *}, * *$ and ${ }^{*}$ sign indicates the significance of the coefficients at $1 \%, 5 \%$ and $10 \%$ significant level respectively.

As it is shown in Table-6, the estimated coefficients of labor force, health human capital and education human capital, policy change dummy and drought dummy have the hypothesized signs while gross capital formation, government expenditure and official development assistance have unexpected signs. In addition, the estimated coefficients of education human capital, health human capital, government expenditure, official development assistance, and drought dummy are statistically significant while labor force, gross capital formation, and policy dummy are not statistically significant.

Since I have specified my growth model in a log-linear form, the coefficient of the dependent variable can be interpreted as elasticity with respect to real GDP per capita. The coefficient of health is 0.5929 . This indicates that, in the long run, holding other things constant, a one percent change in health (proxied by the ratio of public health expenditure to GDP) brought 0.5929 percent change in real GDP. Next to health, education has significant long run impact on the Ethiopian economy .A one percent increase in secondary school enrolment has resulted in 0.5096 percent change in real GDP per capita. The findings of this research concerning the long run positive impact of the education and health human capital are consistent with the endogenous growth theories (mainly advocated and/or developed by Lucas (1988), Romer (1990), Mankiw, Romer and Weil (1992)) which argue that improvement in human capital (skilled and healthy workers) leads to productivity improvement that enhances output. With respect to the researches made in Ethiopia, the finding of this research is also similar to Teshome (2006) and Tofik (2012).

On the other hand, government expenditure and official development assistance and drought have a significant negative impact to the Ethiopian economy. The significant negative impact of government expenditure on the Ethiopian economy is consistent with the findings of Tofik (2012) and Teshome (2006) entailing the dominance of the unproductive and inefficient government spending that could not add any value to the economy (like wages and salaries, rent, debt servicing and transfer payments). The finding of this research in relation to ODA is also similar to the findings of Rajan and Subramanian (2005), Ekanayake and Chatrna (2008), Mallik (2008), and Tasew (2011). Labor force growth has no any significant impact on real GDP per capita. This may be due to the combined effect of high population growth and low productivity of the labor force. Further, the unexpected sign of gross capital formation is similar to the findings of Martha (2008) and Tadesse (2011). The unexpected sign of the coefficient of GCF contradicts with economic growth theories. In my opinion, it may be data and/or valuation problem, but it is difficult to justify the exact reason behind such unexpected result using this research. Hence, further detailed research should be done to identify the reason behind such result (unexpected sign of GCF).

\section{Long-run diagnostic tests}

To check the verifiability of the estimated long run model, some diagnostic test is undertaken. The results reported in Table- $6 n$ indicate that there is no error autocorrelation and heteroskedasticity, and the errors are normally distributed. In addition the Ramsey functional form test confirms that the model is specified well .Hence, the relationship between the variables is verifiable or valid.

Table 5: Long-run diagnostic tests

\begin{tabular}{|l|l|l|}
\hline Test Statistics & LM Version & $\mathrm{F}$ Version \\
\hline Serial Correlation & $\mathrm{CHSQ}(1)=$ & $\mathrm{F}(1,14)=$ \\
test & $0.58187[0.446]^{* *}$ & $0.23668[0.634]^{* *}$ \\
Functional Form & $\mathrm{CHSQ}(1)=$ & $\mathrm{F}(1,14)=$ \\
test & $1.06340[0.302]^{* *}$ & $0.43869[0.519]^{* *}$ \\
Normality test & $\mathrm{CHSQ}(2)=$ & Not \\
& $0.79174[0.673]^{* *}$ & applicable \\
Heteroscedasticity & $\mathrm{CHSQ}(1)=$ & $\mathrm{F}(1,33)=$ \\
test & $0.00974[0.921]^{* *}$ & $0.00919[0.924]^{* *}$ \\
\hline
\end{tabular}

Source: Author's Calculations.

Note: The sign ** indicates the significance of the coefficients at $5 \%$ level of significance. The test for serial correlation is the LM test for autocorrelation, the test for functional form is Ramsey's RESET test, the test for normality is based on a test of skewness and kurtosis of residuals, the test for heteroskedasticity is based on the regression of squared residuals on squared fitted values.

In addition to the above diagnostic tests, the stability of long run estimates has been tested by applying the cumulative sum of recursive residuals (CUSUM) and the cumulative sum of squares of recursive residuals (CUSUMSQ) test. Such tests are recommended by Pesaran and Shin $(1999,2001)$.

Since the test statistics of this stability tests can be graphed, we can identify not only their significance but also at what point of time a possible instability (structural break) occurred. If the plot of CUSUM and CUSUMSQ statistic moves between the critical bounds (at 5\% significance level), then the estimated coefficients are said to be stable. 


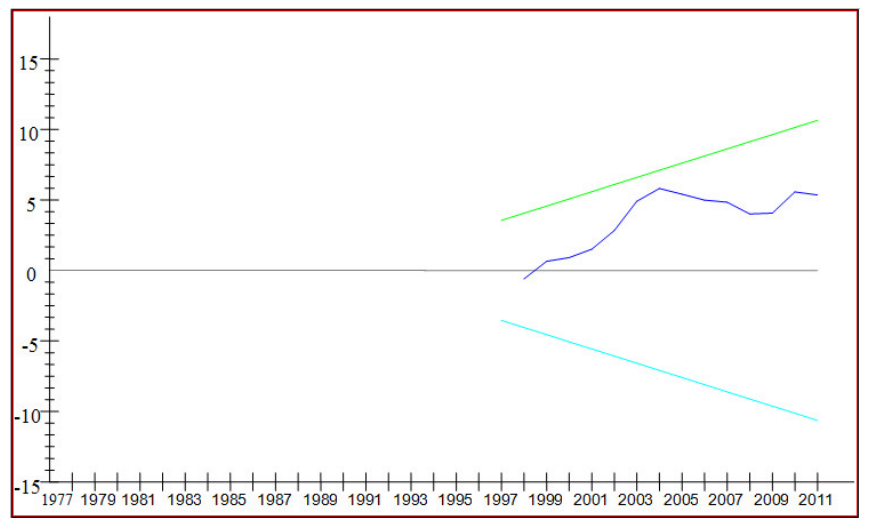

Fig 1: Plot of cumulative sum of recursive residuals Source: Author Calculations

Note: The straight lines represent critical bounds at 5\% significance level

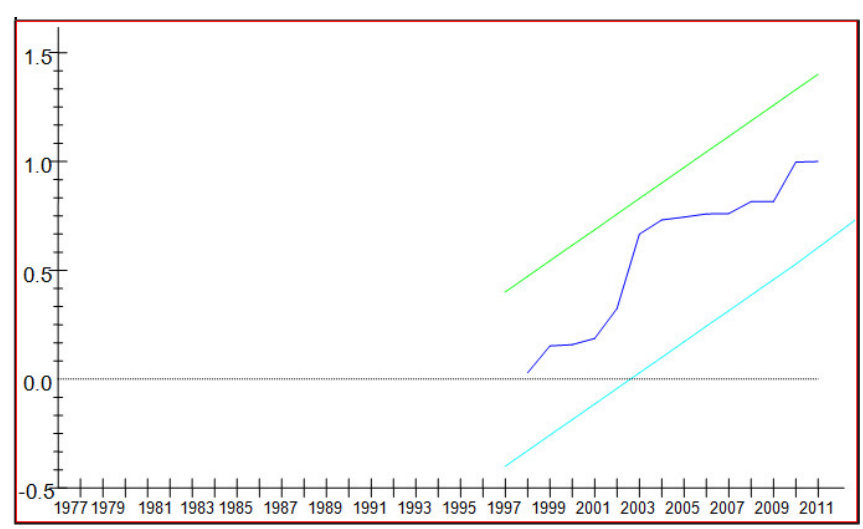

Fig 2: Plot of cumulative sum of squares of recursive residuals

Source: Author Calculations.

Note: The straight lines represent critical bounds at $5 \%$ significance level

The results of both CUSUM and CUSUMSQ test are reported in Figures 1 and 2. As can be seen from the first figure, the plot of CUSUM test did not cross the critical limits. Similarly, the CUSUMSQ test shows that the graphs do not cross the lower and upper critical limits. So, we can conclude that long and short runs estimates are stable and there is no any structural break. Hence the results of the estimated model are reliable and efficient.

\section{CONCLUSION}

The main objective of the study was to analyze the impact of human capital development on economic growth in Ethiopia (using real GDP per capita, as a proxy for economic growth). To determine the impact of human capital development on economic growth (real GDP per capita), the study has used the ARDL Approach to cointegration and the error correction model (ECM).

The main finding of this paper is that in the long run health human capital (proxied by the ratio of public health expenditure to GDP) and education human capital (proxied by secondary school enrolment) are the main contributors to real GDP per capita rise. In other words, the result reveals that economic performance can be improved significantly when the ratio of public expenditure on health services to GDP increases and when secondary school enrolment improves. Holding other things constant, a one percent change in health (proxied by the ratio of public health expenditure to real GDP) brought 0.5929 percent change in real GDP. Next to health, education has significant long run impact on the Ethiopian economy .A one percent increase in secondary school enrolment has resulted in 0.5096 percent change in real GDP per capita. However, government expenditure, official development assistance and recurrent drought have negative impact on the economy. The findings of this research concerning the long run positive impact of the education and health human capital are consistent with the endogenous growth theories (mainly advocated and/or developed by Lucas (1988) , Romer (1990), Mankiw, Romer and Weil (1992) which argue that improvement in human capital (skilled and healthy workers) leads to productivity improvement and thereby output growth. With respect to the researches made in Ethiopia, the finding of this research is also similar to Teshome (2006) and Tofik (2012).

In the short run, the coefficient of error correction term is 0.7366 suggesting about 73.66 percent annual adjustment towards long run equilibrium. This is another proof for the existence of a stable long run relationship among the variables. The estimated short-run model reveals that education is the main contributor to real GDP per capita change followed by gross capital formation (one period lagged value) and government expenditure (one period lagged value). When enrolment increases by one percent, real GDP per capita increases by 0.7686 percent while the same percentage change in one period lagged value of it resulted in about 0.7150 percent rise in real GDP per capita. But, unlike its long run significant impact, health has no significant short run impact on the economy. Even its one period lag has a significant and negative impact on the economy. This could be due to the reason that health expenditure may have big impact on the people who have no positive impact on the economy. As a result, dependency ratio may increase that dilute resources of the economy that would have been invested in creating new assets and values.

A causality test result indicates that there is a Unidirectional causal relationship from health to real GDP per capita while a Bi-directional relationship is identified between real GDP per capita and education. On the other hand, when the lag length of the VAR increases to two, there is no any significant causality between real GDP per capita, education human capital and health human capital.

\section{POLICY IMPLICATION}

The results of this study have important policy implications. In order to improve economic growth, public expenditure needs to be better prioritized towards basic health service provision. In addition, to achieve 
economic growth, more resources should be devoted to educate the citizens of the country. Such measures have a large impact on human productivity which leads to improved national output per capita. In other words, as more people become educated and healthy, they will increase their productivity in the long run. Although not investigated in this paper, one of the ways through which education and health affects economic wellbeing is its externalities effect. That means, education and health may have indirect benefits (positive spillovers) that enhance productivity in the long run.

Hence policy makers and / or the government should strive to create institutional capacity that increase school enrolment and improve basic health service. That means, the policy makers and the government should center on securing more resources and structures that are essential and appropriate for better school enrolment and improved basic health service provision. Such measures should focus not only on creating new institutional capacity, but also on strengthening and changing the existing institutional setups of the education and health sectors of Ethiopia that produce quality manpower. In addition, the government should also continue its leadership role in creating enabling environment that encourage better investment in education and health by the private sector. Because, healthier participation of the private sector in the education and health sectors can speed up the creation of human capital in Ethiopia.

\section{REFERENCES}

Ahmed AA and Dey MM. 2011. Accounting Disclosure Scenario: An Empirical Study of the Banking Sector of Bangladesh Accounting \& Management Information Systems, 9.

Ahmed AA and Neogy TK. 2009. Merger \& Acquisitions (M\&A) Goodwill Accounting: Principles and Practice The Bangladesh Accountant, 65, Oct-Dec.

Ahmed AA and Neogy TK. 2010. Forensic Accounting in Bangladesh: Emergence And Introduction, Development Compilation, 3, 71-82.

Ahmed, M. (2015). The Role of Self-esteem and Optimism in Job Satisfaction among Teachers of Private Universities in Bangladesh. Asian Business Review, 1(2), 114-120.

Alam, S. (2015). Factors Affecting Job Satisfaction, Motivation and Turnover Rate of Medical Promotion Officer (MPO) in Pharmaceutical Industry: A Study Based in Khulna City. Asian Business Review, 1(2), 126-131.

Appleton, S. and F. Teal (1998).Human Capital and Economic Development. A Background Paper Prepared for the African Development Report.

Awan, A. (2015). Shifting Global Economic Paradigm. Asian Business Review, 4(3), 35-40.

Barro, R.J, and J. Lee (2010) .A new Data Set of Educational Attainment in the World, 1950-2010: NBER Working Paper No 15902. Cambridge, Massachusetts.

Barro, R.J. and X. Sala-i-Martin (2004). Economic Growth. $2^{\text {nd }}$ Edition, Cambridge, Massachusetts, London, England: The MIT Press.

Benhabib, J. and M. Spiegel (2002).Human Capital and Technology Diffusion: FRBSF Working Paper No 2003-02. New York University and Federal Reserve Bank of San Francisco

Chowdhury, A., Chowdhury, M., \& Imran, M. (2015). Branding strategies for service firms- a study on the selected Internet Service Providers (ISPs) in Bangladesh. Asian Business Review, 2(1), 47-53.
Duma, N. (2007). Sri Lanka's Sources of growth. IMF working paper No. $07 / 225$.

Easterly, W, (1993). How Much Do Distortions Affect Growth? Journal of Monetary Economics, 32(2):187-212.

Economics Research Unit Discussion Paper No 42. Caulfield, Australia: Department of Economics, Faculty of Business \& Economics, Monash University,

Ekanayake, E.M and D. Chatrna (2008). The Effect of Foreign Aid on Economic Growth in Developing Countries. Journal of International Business and Cultural Studies:1-13

Goldsteine, M., and M. Khan (1976). Large versus Small Price Changes and the Demand for Imports. International Monetary Fund, 23(1): 200-225.

Gundlach, E. (1996). Human capital and economic development: A Macroeconomic Assessment. Kieler Arbeitspapiere Working paper No 778. ECONSTOR, The Open Access Publication Server of the ZBW - Leibniz Information Centre for Economics.

Harbison, F.H (1971). Human Resources as the Wealth of Nations. Proceedings of the American Philosophical Society, 115(6):426-431.

Karagiannis, S. and K. Benos (2009). The Role of Human Capital in Economic Growth: Evidence from Greek Regions. Centre for Planning and Economic Research No 105, Athens, Greece.

Kefela, G. and R. Rena (2007). Human Capital Investment Is a Continuous Proposition: A Study of North East African States. Indus Journal of Management \& Social Sciences, 2(1):54-70.

Lucas, R.(1988). On the Mechanics of Economic Development.Journal of Monetary Economics, 22(1988):3- 42.

Madsen, B. Saxena ,S. and B. Ang (2008). The Indian Growth Miracle and Endogenous Growth. Discussion paper No17/08. Department of Economics, Monash University of Business and Economics.

Mankiw, G., Romer, D. and N. Weil (1992). A Contribution to the Empirics of Economic Growth. Quarterly Journal of Economics, 107 (2): 407-437.

Martha, H.(2008). Productivity and Human Capital: The case of Ethiopia. Unpublished Masters Thesis. Oslo University, Oslo, Norway.

Narayan, P. (2005). The Saving and Investment Nexus for China: Evidence from Co-integration Tests .Applied Economics, 37: 1979-1990.

Pesaran, H. and Y. Shin (1999).An Autoregressive Distributed Lag Modeling Approach to Co-integration Analysis, Cambridge, England.

Pesaran, H., Shin,Y.,and R. Smith (2001). Bounds Testing Approaches to the Analysis of Level Relationships. Journal of Applied Econometrics, 16(3):1924-1996.

Qadri, F. and A. Waheed (2011). Human Capital and Economic Growth: Time Series Evidence from Pakistan. Pakistan Business Review ,1: 815-833.

Rajan, R. and A. Subramanian (2005). Aid and Growth: What Does the Cross-Country Evidence Really Show? International Monetary Fund Working Paper No 05/127.

Romer, P.(1990). Endogenous Technical Change. The Journal of Political Economy, 98(5): S71-S102.

Sarmad, K.(1988). The Functional Form of the Aggregate Import Demand Equation: Evidence from Developing Countries. The Pakistan Development Review, 27(3): 309-315.

Seid , N. (2000). The Determinants of Economic Growth in Ethiopia, Msc. Unpublished Thesis, School of Graduate Studies, A.A.U, Ethiopia. National Bureau of Economic Research working paper series No 8365. Massachusetts, Cambridge.

Tadese, D.B.(2011). Sources of Economic Growth in Ethiopia.A Time Series Empirical Analysis. Unpublished Master's Thesis, Department of Economics, University of Oslo, Oslo.

Teshome, K. (2006). The impact of government spending on economic growth: the case of Ethiopia: unpublished thesis, Addis Ababa University, Addis Ababa, Ethiopia.

Tofik, S. (2012). Official Development Assistance (ODA), Public Spending and Economic Growth in Ethiopia. Journal of Economics and International Finance, 4(8):173-191.

Viste, E., Korecha, D., and A. Sorteberg (2012). Recent Drought and Precipitation Tendencies in Ethiopia. Theor Appl Climatol, 112: 535-551. 
Webb, P., Braun, J. and Y. Yisehac (1992).Famine in Ethiopia: Policy Implications of Coping Failure at National and Household level .Research Report number 92: International Food Policy Research Institute, Washington DC.

Weil, N. (2009). Economic growth. $2^{\text {nd }}$ edition, Prentice Hall publishing, New Jersey, USA.
Woubet, K. (2006). Human Capital and Economic Growth in Ethiopia: Unpublished Master's Thesis, Addis Ababa University, Addis Ababa, Ethiopia, pp.22.

$--0-$ 